\title{
Osteoporozda farmakolojik tedavi
}

\author{
Pharmacological treatment of osteoporosis \\ Yeşim Kirazlı D \\ Ege Üniversitesi Tıp Fakültesi, Fiziksel Tıp ve Rehabilitasyon Anabilim Dalı
}

\section{Öz}

Osteoporoz tedavisinde kullanılan ajanlar genellikle iyi tolere edilir ve oldukça etkindirler. Bisfosfonatlar ve RANKL inhibitörü denosumab gibi antirezorptifler en sık kullanılan osteoporoz ilaçlarıdır. Bu ajanlar postmenopozal osteoporozlu kadınlarda kemik mineral yoğunluğunu artııırlar ve vertebral kırık (\%40-70), vertebra dışı kırık (\%25-40) ve kalça kırık (\%40-53) riskini azaltırlar. Şiddetli osteoporozu ve yüksek kırık riski olan hastalarda, tek başına bisfosfonatlar kırıklara karşı uzun vadeli koruma sağlayamayabilirler. Bu hastalar için, ardışık tedavi, kemik yapıcı bir ajanla (teriparatid) tedaviye başlanması ve bunu antirezorptiflerin izlemesi daha iyi bir uzun vadeli kırık engellenmesi sağlayabilir ve osteoporoz tedavisinin geleceği için altın standart olmalıdır. Bir hasta için ilaç seçimi tamamen hastayı tedavi edecek klinisyene bağlıdır ve hastanın genel sağlık durumu, tedaviye uyumu, tedavi ajanı tercihi, tedavi ajanlarının risk/ yararları düşünülerek ve ülkelerin sağlık sistemi ve özel koşulları göz önünde bulundurularak, osteoporoz tanı ve tedavi kılavuzlarının önerileri doğrultusunda karar verilir.

Anahtar Sözcükler: Antirezorptif ilaçlar, anabolik ajanlar, osteoporoz.

\begin{abstract}
The drugs that are used in the treatment of osteoporosis are usually well tolerated and highly effective. Antiresorptive drugs, such as the bisphosphonates and the RANKL inhibitor denosumab, are currently the most widely used osteoporosis medications. These drugs increase bone mineral density (BMD) and reduce the risk of vertebral (by 40-70\%), nonvertebral (by 25-40\%) and hip fractures (by 40-53\%) in postmenopausal women with osteoporosis. For patients with severe osteoporosis and high fracture risk, bisphosphonates alone are unlikely to be able to provide long-term protection against fracture and restore BMD. For those patients, sequential treatment, starting with a bonebuilding drug (e.g. teriparatide), followed by an antiresorptive, will likely provide better long-term fracture prevention and should be the golden standard of future osteoporosis treatment. The choice of medical treatment depends totally on the clinician who treats the patient and the decision is made according to the patient's preferences, adherence to treatment, the health system of the country and the guidelines.
\end{abstract}

Keywords: Antiresorptive drugs, Anabolic agents, Osteoporosis.

\section{Giriş}

Osteoporoz tedavisinde kullanılan ajanlar genellikle iyi tolere edilir ve kırıkları engelleme konusunda oldukça etkindirler. Bu bölümde osteoporoz tedavisi konusundaki gündemdeki stratejilerden bahsedilirken, konuyla ilgili güncel tanı ve tedavi kılavuzlarından da söz edilecektir.

Postmenapozal osteoporozun önlenmesi ve/veya tedavisi için onay almış ajanlar alfabetik sıraya göre şunları içermektedir: bisfosfonatlar (alendronat, ibandronat, rizedronat, zoledronik asid), denosumab, kalsitonin, parathormon [PTH (1-34), teriparatid], raloksifen ve stronsiyum ranelattır (1) (Tablo-1).

\footnotetext{
Yazışma Adresi: Yeşim Kirazlı

Ege Üniversitesi Tıp Fakültesi, Fiziksel Tıp ve Rehabilitasyon Anabilim Dalı

E-mail:yesim.kirazli@gmail.com
}

Tümünün kemik mineral yoğunluğunu değişik derecelerde arttırdığı ve vertebra kırık riskini azalttıkları gösterilmiştir. Bazı ajanların ayrıca vertebra dışı kırık riskini, bazı durumlarda da kalça kırık riskini azalttıkları saptanmıştır ${ }^{2}$. Genel olarak, farmakoterapi kırık riskini \%30-70 arasında azaltır. Vertebra dışı kırıklar üzerindeki etki daha düşüktür ve kırık bölgesine göre değişir. Antirezorptif ajanlar kırık riskini başlangıçta kemik rezorpsiyonunu ve kemik porozitesini hızla azaltarak ve bunu takiben kemik mineral yoğunluğu (KMY) nu arttırarak azaltırlar. Osteoporoz tedavisinde kullanılan ajanların çoğunluğu antirezorptif ajanlardır. Anabolik ajanlar ise KMY'yi progresif olarak arttırarak, kemik trabeküllerinin sayısını ve kemik büyüklüğünü arttırarak işlev görürler. Parathormon (PTH) osteoporoz tedavisi için ülkemizde onay almış olan tek anabolik ajandır. Diyetle ve destek tedavi yoluyla alınan kalsiyum ve $D$ vitamininin osteoporoz 
tedavisinde tek başına kullanılması yeterli olmamakla birlikte, sağlıklı kemik fizyolojisi açısından diğer ajanlarla birlikte kullanılmaları mutlaka gerekmektedir.

Tablo-1. Osteoporozda tedavi seçenekleri.

\section{Osteoporozda Tedavi Seçenekleri}

\begin{tabular}{ll} 
Antirezorptif ajanlar & Anabolik ajanlar \\
\hline - Bifosfonatlar & \\
Alendronate & ParaThyroid Hormon \\
$-\quad$ Zbandronate & rhPTH(1-34)=Teriparatid \\
- Risedronate & \\
- Strontium ranelate & \\
Selektif Östrojen Reseptör & Modülatörleri (SERM) \\
Raloksifene & \\
- Denosumab &
\end{tabular}

Tablo-2. Farmakolojik ajanların kırıklar üzerindeki etkileri (2).

\begin{tabular}{|c|c|c|c|}
\hline & Vertebra kırığı & $\begin{array}{l}\text { Non-vertebral } \\
\text { kırık }\end{array}$ & Kalça kırığı \\
\hline Alendronat & + & + & + \\
\hline Rizedronat & + & + & + \\
\hline Ibandronat & + & Bazı hasta grubu & Kanıt yok \\
\hline Zoledronik asid & + & + & + \\
\hline Denosumab & + & + & + \\
\hline Raloksifen & + & Kanit yok & Kanit yok \\
\hline Stronsiyum & + & + & $\begin{array}{l}\text { Bazı hasta } \\
\text { grubu }\end{array}$ \\
\hline Teriparatid & + & + & Kanıt yok \\
\hline
\end{tabular}

\section{Bisfosfonatlar}

\section{Alendronat}

Kemik kaybının engellenmesinde, postmenopozal osteoporoz tedavisinde, osteoporozlu erkeklerde kemik kütlesinin arttırılmasında ve glukokortikoid osteoporozu tedavisinde FDA onayı almıştır. $10 \mathrm{mg}$ günlük doz ve 70 $\mathrm{mg}$ haftalık dozu bulunmaktadır. $70 \mathrm{mg}$ haftalık tabletin 2,800 IU veya 5,600 IU Vitamin D3 ile kombinasyonu da onay almıştır. Yurt dışında ayrıca $5 \mathrm{mg}$ günlük ve $35 \mathrm{mg}$ haftalık dozu bulunmaktadır (3).

\section{Rizedronat}

Kemik kaybının engellenmesinde, postmenopozal osteoporoz tedavisinde, osteoporozlu erkeklerde kemik kütlesini arttırmak için tedavide ve glukokortikoid osteoporozu önlem ve tedavisinde FDA onayı almıştır. 5 $\mathrm{mg}$ ve $35 \mathrm{mg}$ 'ık tabletleri bulunmaktadır. Osteoporozun hem önlenmesi hem de tedavisinde önerilen doz günde $5 \mathrm{mg}$ veya haftada bir kez $35 \mathrm{mg}$ veya ayda üst üste iki gün $75 \mathrm{mg}$ olarak kullanılmasıdır. Yurt dışında ayrıca $150 \mathrm{mg}$ 'ık tableti bulunmaktadır (3).

\section{Ibandronat}

Osteoporoz hem önlenmesi hem de tedavisinde önerilen doz günde $2.5 \mathrm{mg}$ tablet veya ayda bir kez (her ayın aynı tarihinde) $150 \mathrm{mg}$ tablet alınmasıdır. Eğer ayda bir kez alınan doz unutulursa ve bir sonraki ilacın alınma süresine yedi günden fazla varsa, hasta ilacı alması gerektiğini hatırladığı gün bunu izleyen sabah ilacını alır. İlacını daha sonra orijinal planda belirlenmiş günde ayda bir kez olarak almaya devam eder. Hasta aynı hafta içinde iki adet $150 \mathrm{mg}$ tablet almamalıdır. Eğer ayda bir kez alınan doz unutulursa ve bir sonraki ilacın alınma süresine 1- 7 gün varsa, daha önceden planlanmış olan güne kadar bekler ve o zaman ilacını alır. Her üç ayda bir $3 \mathrm{mg} \mathrm{IV}$ formu da osteoporoz tedavisi için onay almıştır. İbandronat 3 ml'de $3 \mathrm{mg}$ olacak şekilde hazır bir şırınga şeklindedir ve IV enjeksiyon 15-30 saniye içinde yapılır (3)

Oral bisfosfonatlar uzun süreli açlık sonrası (genellikle tüm gece aç kaldıktan sonra) boş mideye, ilk yiyecek, içecek veya oral ilaçlardan en az yarım saat önce (alendronat ve rizedronat için yarım saat, ibandronat için bir saat) suyla alınmalıdır. Herhangi bir yiyecek, su dışı içecek, bazı oral ilaçlarla birlikte alınması veya yemekten sonraki iki saat içinde alınması absorpsiyonu belirgin derecede etkiler. Özefagus iritasyonunu engellemek için mutlaka bir bardak suyla alınmalı ve hasta kahvaltı edinceye kadar oturur pozisyonda veya ayakta dik olarak durmalıdır.

\section{Zoledronik asit}

Zoledronik asit postmenopozal osteoporozlu kişilerde vertebral, nonvertebral ve kalça kırıklarının engellenmesinde etkinliğinin gösterilmiş olması nedeniyle postmenopozal osteoporoz tedavisinde onay almıştır. Ayrıca FDA iki yılda bir yapılacak uygulamaya postmenopozal osteoporoz önlenmesi için onay vermiştir. En az 12 ay süreyle glukokortikoid tedavisi alması beklenen kadın ve erkeklerde osteoporozun tedavisi ve önlenmesi için de onaylanmıştır. Ayrıca osteoporotik kalça kırığı sonrasında yeni gelişecek klinik kırıkların engellenmesinde FDA onayı almış olan tek ajandır (3).

Yılda bir kez, $5 \mathrm{mg}$ (100 ml solüsyon içinde) dozda, intravenöz olarak en az 15 dakikada verilecek şekilde uygulanır. Yılda tek doz uygulama hasta uyumunu arttıracağı ve etkinliği pekiştireceği için önemli bir avantaj sayılabilir.

\section{Bisfosfonat (BP) Tedavisi ile Görülen Yan Etkiler}

Yan etkiler tüm oral BP'ler için benzerdir. Yan etkiler genellikle hafiftir ve primer olarak üst gastrointestinal sistemi etkiler. Oral BP'lerle ilgili güvenlik konusu en çok üst gastrointestinel sistem (ÜGS) mukozası ile ilgilidir. Büyük çaplı klinik çalışmalarda BP'ler ve plasebo arasında tolerabilite açısından belirgin farklılık gözlenmemiştir. Ancak klinik pratikte midede yanma, 
substernal rahatsızlık hissi ve yutma zorluğu gibi üst gastrointestinal semptomlar gözlenebilir.

Özefagus erozyonu, gastrik ülser veya kanama gibi çok nadir olgular bildirilmiştir. Ancak aminobisfosfonatların çok nadir de olsa özefajit oluşturabileceği ve bu problemin tedavinin herhangi bir aşamasında (sadece başlangıçta değil) görülebileceği unutulmamalıdır. Bazı çalışmalarla oral ajan kullanımı ve özefagus kanseri arası ilişki gündeme getirilmiştir. Ancak FDA bu konuda kesin bir ilişkinin olmadığını belirtmiştir.

İntravenöz BP uygulamalarında infüzyondan sonraki 1-3 gün içinde ateş, miyalji, grip benzeri, artralji, baş ağrısı gibi akut faz reaksiyonu görülür. Bu yan etkiler 1-3 gün içinde kaybolur. En fazla ilk enjeksiyondan sonra görülüp, takip eden enjeksiyonlardan sonra görülme oranı daha da azalır. Parasetamol veya ibuprofen uygulaması semptomları gidermede başarılıdır. Hızlı IV uygulama yaşlı kişilerde, dehidratasyonu olanlarda, diüretik veya potansiyel nefrotoksik ajan kullananlarda renal fonksiyonlarda bozulmaya neden olabilir.

Zoledronik asitle yapılan postmenopozal osteoporoz çalışmasında atrial fibrilasyon plasebo grubundan daha yüksek oranda gözlenmiştir. Ancak diğer zoledronik asitle yapılmış osteoporoz çalışmalarında ve onkoloji grubunda böyle bir yan etki görülmemiştir. Daha önceden bilinen kardiyovasküler hastalığı olan yaşlılarda izlem uygun olabilir (4).

Antirezorptif tedaviler ile çene osteonekrozu ve atipik femur kırıkları ilişkisi gündeme getirilmiştir (5).

Çene osteonekrozu diş çekimi, dental implant uygulaması sonrasında, çok nadiren de kendiliğinden oluşan mandibula veya maksillada yer alan ve haftalarca (>8 hafta) devam eden açık bir yaradır. Bu hastaların çoğunluğu bisfosfonat tedavisi alan onkoloji hastalarıdır (olguların \%94'ü). İlk olarak yüksek doz BP tedavi alan ileri kanser hastalarında raporlanmıştır. Osteoporoz dozunda BP alan osteoporotik popülasyonda çene osteonekrozu gelişimi riski 1/10.000 - 1/100.000 hastayılında kadar düşük oranlardadır. Çeşitli ülkelerde diş hekimleri dernekleri ve ASBMR konuyla ilgili kılavuzlar yayınlamıştır. Bu önerilerin çoğunluğu risk/yarar oranı hesaplamasına, uygun dental hijyenin sağlanmasına dayanmaktadır; bilim ve kanıtlardan ziyade görüşlere yer verilmektedir. Risk faktörleri dental patolojik durumlar, invaziv işlemler ve kötü ağız içi hijyenidir. Antirezorptiflerle tedavi düşünülen hastalarda oral muayene yapılır, eğer belirgin dental sorunlar varsa bu sorunlar düzelinceye kadar antirezorptif tedavi ertelenir. Zaten osteoporoz için tedavi almakta olan hastalarda tedavinin bırakılmasının veya ara verilmesinin çene osteonekrozu riskini azaltıp azaltmayacağına yönelik kanıt yoktur. Tedavi almakta olan hastalarda ise diş cerrahisi yapılmadan üç ay önce geçici olarak BP'ler bırakılması ve oral doku iyileştikten sonra tekrar başlanması uzman önerileri arasında sayılıp, kanıt olmadığı belirtilmelidir (6).

Atipik femur kırıkları subtrokanterik veya diyafizyel bölgelerde gelişir. Çok nadir de rastlansa, uzun süreli BP tedavisi alanlarda daha sık görülür (7). Bu kırıklar transvers veya oblik olarak gerçekleşir. Bu hastaların \%70 kadarında prodromal uyluk veya kasık ağrısı olur. Bisfosfonat tedavisi altında olup, uyluk/kasık ağrısı gelişenlerde uygun görüntüleme yöntemleri tamamlanıncaya kadar tedavi durdurulmalıdır. Radyografik olarak lateral periostal stres reaksiyonu, kortikal kalınlaşma görülür. Klinik bulguların varlığında, direkt radyografide patoloji saptanmazsa kemik sintigrafisi ve MR görüntüleme gibi tetkiklere başvurulur.

\section{Kontrendikasyonlar}

Hipokalsemi durumunda kullanılmamalıdır. Tüm BP'ler ilaç hipersensitivitesi olanlarda, hipokalsemik hastalarda ve ağır böbrek yetersizliğinde (ibandronat ve rizedronat için GFR $<30 \mathrm{~mL} / \mathrm{dk}$; alendronat ve zoledronik asit için GFR<35 mL/dk) kullanılmamalıdır. Bunun dışında doz ayarlaması gerekmez. Herhangi bir BP tedavisine başlamadan önce hipokalsemi ve diğer mineral metabolizma bozuklukları düzeltilmelidir. Hafif-orta dereceli renal yetmezliği olanlarda (kreatinin klirensi 35$60 \mathrm{~mL} /$ dakika) doz ayarlaması gerekmemektedir. Oral ajanların kullanımına aktif özefagus hastalığı durumunda çok dikkat edilmelidir. Diğer kontrendikasyonlar oral kullanım kurallarına uyamama, 30-60 dk dik duramama, ilaç transferini geciktirebilecek özefagus sorunları (akalazia, dismotilite, striktür), Gi malsabsorpsiyon olasılığıdır (gastrik bypass, Crohn hastalığı, çöliyak hastalığı vs.).

\section{Bisfosfonatlarla Tedavi Süresi ve İlaç Tatili}

BP'ler değişik süreler boyunca kemikte kalırlar; yararlı etkiler tedavi bitiminden sonra bir süre devam eder. Bu nedenle bir süre tedaviden sonra tedaviye ara verilmesinin mümkün olabileceği düşünülmüş, diğer bir deyişle ilaç tatili kavramı gelişmiştir. Tedavinin bırakılmasıyla kemik biyokimyasal belirleyicilerinde yeniden yükselme ile beraber BMD düşüşü kırık riskinde de olası bir yükselmeyi düşündürmektedir. Tedavinin bırakılmasıyla alendronat için 2-3 yıl sonra, ibandronat ve rizedronat için 1-2 yıl sonra KMY azalır ve kemik döngüsü artar. Zoledronik asid durumunda ise, üç yıllık tedaviden sonra tedavinin bırakılması durumunda, tedavinin bırakılmasından sonraki bir üç yıl daha KMYde çok az miktarda azalmayla ilişkilidir. Birçok otör üç yıllık IV ve beş yıllık oral BP tedavisinden sonra hastaların gözden geçirilmesini önerirler. 3-5 yıllık BP tedavisinden sonra tedaviye devam etme genellikle aşağıdaki durumlarda önerilir (4).

75 yaş ve üstü, önceki kalça veya vertebra kırığı öyküsü, tedavi süresince düşük travmalı kırık oluşumu 
Tablo-3. Uzun süreli bp tedavisinin takip algoritması (4).

Postmenopozal kadınlarda uzun süreli bisfosfonat tedavisinin takip algoritması

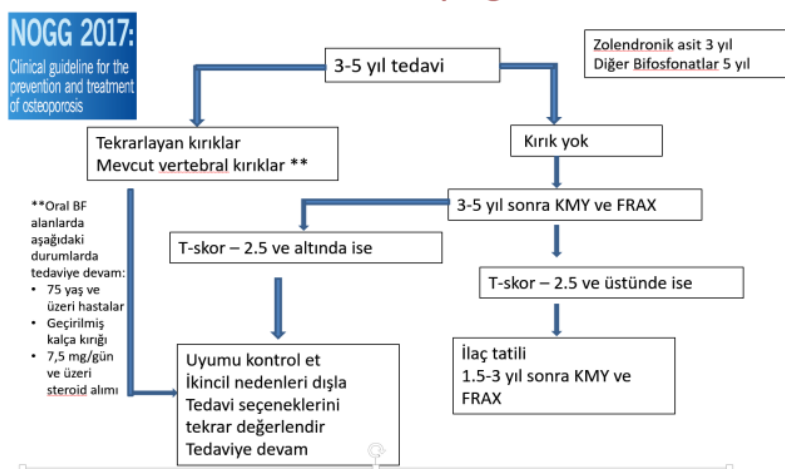

Kırık açısından yüksek riskli hastalar ilaç tatili verilmeksizin osteoporoz tedavisine devam etmelidir.

İlaç tatilinin optimal süresi tanımlanmamıştır. DXA ile ölçüm ilaç tatili başında, 12-18. ayda ve 24-36. ayda yapılmalıdır. İki yılda kalça BMD'de >\%3 kayıp, kırık riski ile koreledir. Kemik rezorpsiyon belirleyicilerinde $>\% 30$ artış tatili kesmek için erken belirleyici kabul edilir. FRAX aracının kullanııması ilaç tatilinin süresine karar vermede yardımcı olabilir.

\section{Denosumab}

Osteoklast gelişimi ve aktivitesinin önemli bir düzenleyicisi olan Nükleer faktör Kappa B Ligand'ın (RANKL) Reseptör Aktivatörüne karşı insan monoklonal antikorudur. RANKLRANK etkileşimini bloke eder. Osteoklast oluşumunu, işlevini ve yaşam süresini azaltır. Yüksek kırık riski olan postmenopozal osteoporozlu kadın hastaların ve erkeklerin tedavisinde endikedir. Hormon ablasyonu uygulanmış, olan nonmetastatik prostat kanserli veya meme kanseri nedeniyle adjuvan aromataz inhibitörü tedavisi gören yüksek kırık riskine sahip hastalardaki osteoporoz tedavisinde endikedir. Ayrıca yüksek kırık riski olan erişkinlerde uzun süreli sistemik glukokortikoid tedavisiyle ilişkili kemik kaybının tedavisinde endikedir. Her altı ayda bir $60 \mathrm{mg}$ subkutan enjeksiyon olarak uygulanır. Osteoporozu olan postmenopozal kadınlarda vertebra, vertebra dışı ve kalça kırığı insidansını azalttığı gösterilmiştir. On yıl boyunca kullanımıyla lumbal vertebra KMYde \%21.7 şeklinde bir artış olmuştur ki; bu oran herhangi bir osteoporoz tedavi ajanıyla elde edilenden çok daha fazladır (10).

\section{Yan Etkiler ve Kontrendikasyonlar}

Hipokalsemi olan veya formülasyonun herhangi bir yapısına karşı aşıı duyarlılığı olan hastalarda kontrendikedir. Kırık sonrası erken dönemde verilebilir. Böbrek fonksiyon bozukluğu olan hastalarda öncelikli tercih olabilir. Illeri evre böbrek hastalarında, diyaliz hastalarında, ilaç hipersensitivitesi olanlarda önerilmez. Çok nadiren atipik femur kırığı ve çene osteonekrozu gösterilmiştir. Tedavi alırken dental girişim gerekirse, tedavi kesilmez. İnvaziv bir girişim yapılacaksa denosumab uygulamasından dört hafta sonra yapılması uygun olur. Bir sonraki denosumab uygulamasından ise en az altı hafta önce yapılması iyi olur (6). 10 yıl süreyle denozumab kullanımının etkin ve güvenilir olduğu gösterilmiştir (8). On yıl boyunca denosumab alan tüm kişiler için advers olay insidansı zamanla azalma eğilimi gösterdi; ciddi advers olaylar stabil kaldı. Dört klinik çalışmanın meta-analizinde plasebo ile karşılaştırıldığında denosumab grubu için ciddi advers olay rölatif riski 1.33, enfeksiyonla ilişkili ciddi advers olay 2.10 , neoplazi 1.11, advers olaylara bağlı çalışmadan çıkma 1.10 olup, tüm bu riskler istatiksel olarak anlamlı değildi. Tedavinin kesilmesiyle 1-2 yıl içinde kemik döngüsü belirleyicileri başlangıç düzeyine döner, $\mathrm{KMY}$ ise 12.-18. ayda başlangıç düzeyine döner. Freedom çalışması sonrasında denosumab tedavisini bırakanlarda gelişen vertebra kırık oranı 100 hasta yılında 7.1 iken, plasebo grubunda bu oran 8.5 şeklindeydi ancak tedaviye bırakan grupta multipl vertebra kırık oranı daha fazlaydı. Bu nedenle denosumab tedavisi sonrası ilaç tatili verilmez; kısa süreli bisfosfonat tedavisi ile tedaviye devam edilir (9).

\section{Raloksifen}

Raloksifen bir selektif östrojen-reseptör modülatörüdür (SERM). Non-hormonal ajan olup, bazı dokularda östrojen agonist, diğerlerinde ise östrojen antagonist etkisi vardır. Raloksifen postmenopozal osteoporoz tedavisi ve önlenmesinde FDA onayı almıştır. Raloksifen ayrıca osteoporozu olan postmenopozal kadınlarda invaziv meme kanseri riskinin azaltılması için endikedir (3).

Raloksifen 60 mg'lık tablet formunda olup, oral olarak kullanılmaktadır. Raloksifenin etkinliği yemekle beraber ve kalsiyum ve $D$ vitamini tabletleriyle birlikte alınması durumunda bile değişmez. Bu nedenle istenildiği şekilde (aç/tok karnına) ve günün her saatinde alınabilir.

\section{Yan Etkiler}

Raloksifen genel olarak güvenilir ve iyi tolere edilebilen bir ajandır. Raloksifen alan kişilerde plasebo ile karşılaştırıldığında sıcak basma (tedavinin ilk altı ayında daha sık) ve bacak kramplarında artış gösterilmekle beraber bu semptomlar genellikle hafiforta derecelidir ve tedavinin bırakılmasını gerektirmez. Diğer yan etkiler içinde periferik ödem, terleme ve endometrial hastalık olmaksızın endometrial sıvı birikimi sayılabilir. Östrojen ve tamoksifenden farklı olarak raloksifen vajinal kanama, endometrial hiperplazi ve endometrial kanser riskini arttırmaz.

Venöz tromboemboli raloksifen tedavisi ile ilişkili ciddi bir yan etkidir; ancak nadiren gözlenir. 1000 hasta yılı için plasebo ve raloksifen grupları için sırasıyla 1.44 ve 3.32 şeklindedir. Raloksifen plasebo ile karşılaştırıldığında venöz tromboembolik hastalık riskini ortalama üç kat (RR: 3.1) arttırır. Rölatif riskin büyüklüğü HRT ve tamoksifenle gözlenene benzer şekildedir. 


\section{Kontrendikasyonlar}

Hamilelerde ve venöz tromboembolik hastalık geçirmiş olanlarda raloksifen kullanımı kontrendikedir. Venöz tromboemboli riski açısından uzun süreli immobilizasyondan bir hafta önce ilacın bırakılması gerekmektedir.

\section{Paratiroid Hormon (PTH)}

PTH ile yeni kemik oluşumu trabeküler konnektivitenin artışı ve kortikal kalınlığın sağlanması ile hem kortikal, hem de trabeküler bölgelerde kemik mikromimarisinin restorasyonunu sağlamaktadır. Rekombinant insan PTH (1-34) fragmanı teriparatid adını almıştır; biyokimyasal sentetik metodlarla oluşturulmuş aminoteminal insan fragmanıdır. Teriparatid günde $20 \mu \mathrm{g}$, PTH (1-84) ise günde $100 \mu \mathrm{g}$ dozunda subkutan enjeksiyon olarak kullanılmaktadır. Teriparatid 28 adet dozu içeren kalem şeklinde cam bir haznede sunulmaktadır. Tedavinin vertebra kırık riskini anlamlı azalttığı ve nonvertebral kırıklar üzerinde de etkili olduğu gösterilmiştir.

\section{Anabolik tedavi için kimler aday olmalıdır?}

PTH tedavisi için uygun adaylar osteoporozla ilişkili kırıklar için yüksek risk altındaki kadın ve erkeklerdir. Bu tanımlama osteoporoz tanı sınırları içinde BMD'si olan ve klinik/radyografik vertebra kırıkları ile diğer osteoporotik kırıkları geçirmiş olan kişileri veya kırıkları olmadığı halde çok düşük BMD'si olanları (T skor < -3 SD) içermektedir (3). Çalışmalarda PTH'ın kırık etkinlik verisi daha önceden tedavi almamış kadınları içersede, PTH daha önceden anti-rezorptif tedavi almış olanlara da gerekiyorsa verilmelidir. Tedaviye suboptimal yanıt verenler (tedavi sırasında kırık geçirenler veya aktif kemik kaybı olanlar) PTH tedavisi için uygun adaylardır.

\section{Yan Etkiler}

Gözlenen yan etkiler hafif ve geçicidir; ortostatik hipotansiyon gelişebilir (genellikle tedavinin bırakılmasını gerektirmez, ilk uygulamalarda gözlenir, hasta yatma pozisyonuna alındığında düzelir). Bacaklarda ağrı, baş ağrısı, bulantı ve sersemlik hissi gelişebilir. Geçici ve asemptomatik hiperkalsemi de gözlenmiştir. Normokalsemik hastalarda her dozdan 46 saat sonra serum kalsiyum konsantrasyonu en üst seviyeye ulaşır; 16-24 saat içinde başlangıç değerine döner. Değişiklik minimaldir ve tedavi sırasında rutin kalsiyum izlemi gerekmemektedir. PTH uygulaması idrar kalsiyum atılımında hafif düzeyde artışa neden olabilir; hiperkalsiüri insidansı plasebo ile tedavi edilenlerden farklı değildir. Ancak bu ajanlar sorunu arttırabilme potansiyelleri nedeniyle aktif veya yeni böbrek taşı öyküsü olanlarda kullanılmamalıdır (2).

\section{Kontrendikasyonlar}

Yüksek doz, uzun süreli teriparatid uygulaması yapılmış olan fare çalışmalarında osteosarkom insidansında artış görüldüğü için, insanlarda böyle bir sonuca rastlanmamakla birlikte PTH anormal yüksek kemik döngüsünün görüldüğü hiperkalsemide, hiperparatiroidi, kemiğin Paget hastalığı gibi primer osteoporoz dışı metabolik kemik hastalıklarında, açıklanamayan alkalen fosfataz yüksekliğinde, iskelete radyoterapi yapılmış olanlarda, kemik primer malign hastalıkları ve kemik metastazında ve epifizleri kapanmamış çocuklarda kullanılmamalıdır. İleri böbrek yetmezliği de kontrendikasyon oluşturmaktadır.

\section{Tedavi Süresi}

PTH tedavisinin uygulandığı çalışmalar 18-24 ay süreyle yapılmış olup, teriparatidin nonvertebral kırıklar üzerindeki etkinliğinin tedavi bitiminden sonra 30 ay süreyle devam ettiği bilinmektedir. Tedavi süresi 24 ayı geçmemelidir.

Daha önce primer son noktası kırık olan ve iki osteoporoz ajanını karşılaştıran çalışma yapılmamış iken, ilk kez VERO çalışmasıyla teriparatid ve rizedronat karşılaştırılmıştır. 24 ay süreli bu çalışmada teriparatidle tedavi edilmiş en az iki orta dereceli veya bir şiddetli vertebra kırığı olan postmenopozal kadınlarda yeni vertebral ve klinik kırık riski rizedronatla tedavi edilen kadınlara göre belirgin olarak daha düşük bulunmuştur (10).

Amerikan Endokrinoloji Derneği Kılavuzuna göre osteoporozda tedavi ajanı seçimi Tablo-4 ve Tablo-5'te sunulmuştur (5).

Tablo-4. Daha önce frajilite kırığı olmayanlarda veya orta dereceli kırık riski olanlarda tedavi ajanı seçimi.

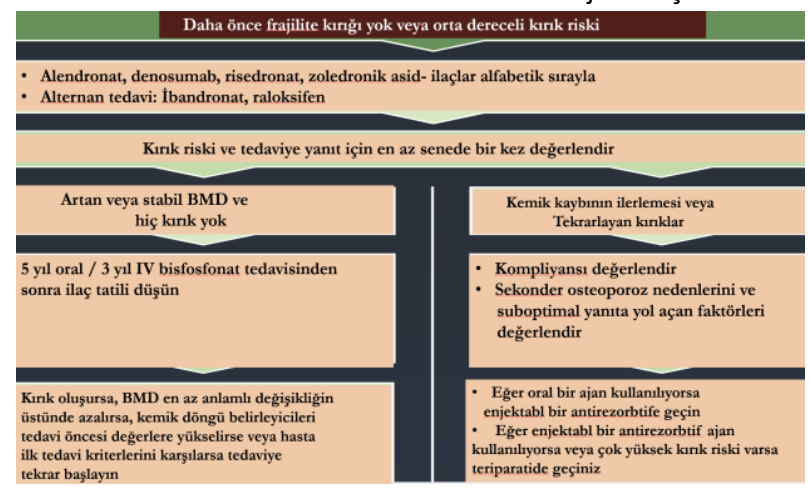

Tablo-5. Daha önce frajilite kırığı olanlarda veya yüksek dereceli kırık riski olanlarda tedavi ajanı seçimi. Daha önce frajilite kirkları veya yüksek kırk riski belirleyicileri varsa

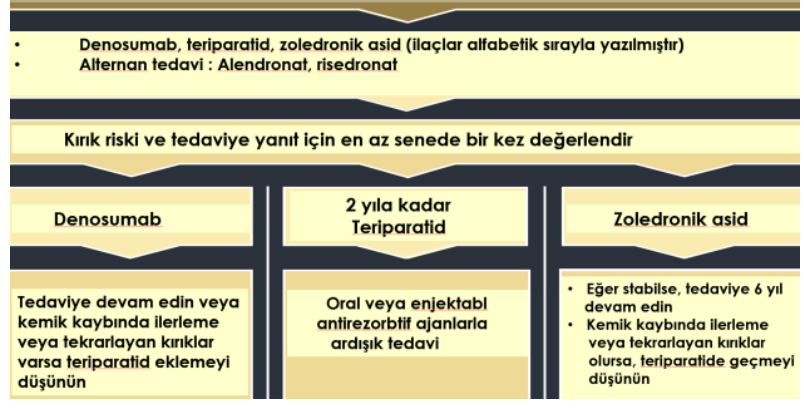




\section{Kombinasyon Tedavileri}

Kombinasyon tedavisinin kırık riski üzerindeki etkisi gösterilene kadar postmenopozal osteoporozun önlenmesi veya tedavisi için birlikte kullanılması önerilmez. Anabolik/antirezorptif tedavinin kombine kullanımını destekleyecek kırık verileri bulunmamasına rağmen, denosumab ve teriparatid kombinasyonu, en yüksek kırılganlık kırığı riski olan hastalarda umut vaat etmektedir (11).

Menopoz semptomlarının tedavisinde östrojen veriliyorsa veya meme kanseri riskini azaltmak için raloksifen uygulanıyorsa, yüksek riskli hastalarda ek bir ajan olarak bisfosfonat, denosumab veya teriparatid düşünülebilir (5).

\section{Ardışık Tedaviler}

Şiddetli osteoporozu ve yüksek kırık riski olan hastalarda, tek başına BP'ler kırıklara karşı uzun vadeli koruma sağlayamayabilirler. Bu hastalar için, ardışık tedavi, kemik yapıcı bir ajanla (teriparatid) tedaviye başlanması ve bunu antirezorptiflerin izlemesi daha iyi bir uzun vadeli kırık engellenmesi sağlayabilir ve osteoporoz tedavisinin geleceği için altın standart olmalıdır (1). Artmış kırık riski olan kişilerde, tedaviye anabolik bir ajanla başlamak en mantıklıdır. Teriparatidin kullanım süresinin 18-24 ayla sınırlandırılmış olup ve tedavi bitince etkinin zamanla kaybolacağı düşünülürse, teriparatid tedavisi bitiminde bir anti-resorptifle tedaviye devam etmek uygun olacaktır (12).

Ardışık tedaviler Tablo-6'te İsviçre Osteoporoz Birliğinin görüşü olarak sunulmuştur (13).

Tablo-6. Osteoporoz tedavisinin optimal hale getirilmesi.

Kısa ve Uzun Süreli Osteoporoz Tedavisi-Optimal Hale getirmek
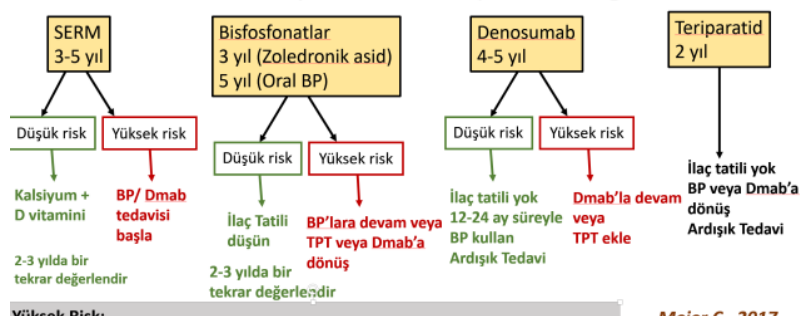

Yüksek Risk

2-3 yilda bir dous

Tedavi öncesindeki 5 yil veya sirasında kalça,vertebra veya multipl krikklar

Yaş <65 ise femur boyun <-2.5 SD; > 65 ise T-skoru <-2.0 SD ve/veya sik düşme öyküsü - Hormon ablasyon tedavisi alma, diabet, düşkūnlük

\section{Sonuç}

Osteoporoz tedavisinde kullanılan ajanlar genellikle iyi tolere edilir ve oldukça etkindir. Bir hasta için ilaç seçimi tamamen hastayı tedavi edecek klinisyene bağlıdır ve hastanın genel sağlık durumu, tedaviye uyumu, tedavi ajanı tercihi, tedavi ajanlarının risk/yararları düşünülerek ve ülkelerin sağlık sistemi ve özel koşulları göz önünde bulundurularak, osteoporoz tanı ve tedavi kılavuzlarının önerileri doğrultusunda karar verilir.

\section{Kaynaklar}

1. Lorentzon M. Treating osteoporosis to prevent fractures: current concepts and future developments. J Intern Med 2019 Jan.doi 10.1111/joim 12873.

2. Kanis JA, Cooper C, Rizzoli R, Reginster JY. Scientific Advisory Board of ESCEO and IOF. European guidance for the diagnosis and management of osteoporosis in postmenopausal women. Osteoporos Int 2019 Jan; 30(1):3-44 .

3. Black DM, Rosen CJ. Clinical Practice. Postmenopausal Osteoporosis. N Engl J Med 2016 Jan 21; 374(3): 254-62.

4. Compston J, Cooper A, Cooper C, et al. UK clinical guideline for the prevention and treatment of osteoporosis. Arch Osteoporos 2017;12:43-67.

5. Camacho P, Petak SM, Binkley N, Clarke BL, Harris ST, Hurley DL. AACE/ACE Postmenopausal Osteoporosis CPG. Endocr Pract 2016;22(Suppl 4):1-36.

6. Di Fede O, Panzarella V, Mauceri R, et al. The Dental Management of Patients at Risk of Medication-Related Osteonecrosis of the Jaw: New Paradigm of Primary Prevention. Biomed Res Int 2018 Sep 16;2018:2684924. doi: 10.1155/2018/2684924.

7. Silverman S, Kupperman E, Bukata S. Bisphosphonate-related atypical femoral fracture: Managing a rare but serious complication. Cleve Clin J Med 2018 Nov;85(11):885-893.

8. Bone HG, Wagman RB, Brandi ML, et al. 10 years of denosumab treatment in postmenopausal women with osteoporosis: results from the phase 3 randomised FREEDOM trial and open-label extension. Lancet Diabetes Endocrinol 2017 Jul;5(7):51323.

9. Lewiecki EM. New and emerging concepts in the use of denosumab for the treatment of osteoporosis. Ther Adv Musculoskelet Dis 2018 Nov; 10(11): 209-23.

10. Kendler DL, Marin F, Zerbini CAF, et al. Effects of teriparatide and risedronate on new fractures in post-menopausal women with severe osteoporosis (VERO): a multicentre, double-blind, double-dummy, randomised controlled trial. Lancet 2018 Jan 20;391(10117):230-40.

11. Lou S, Lv H, Chen Y, Zhang L, Tang P. Use of combination therapy in the treatment of osteoporosis. BMJ Open 2016 Nov 8:6(11):e012802.

12. Leder BZ. Optimizing sequential and combined anabolic and antiresorbtive osteoporosis therapy. JBMR Plus 2018 Feb 27;2(2):62-8.

13. Meier C, Uebelhart B, Aubry-Rozier B, Birkhäuser M, Bischoff-Ferrari H, Frey D. Osteoporosis drug treatment: duration and management after discontinuation. A position statement from the Swiss Association against Osteoporosis (SVGO/ASCO). Swiss Med Wkly 2017;147:w14484. 